\title{
ENTOMOPATHOGENIC NEMATODES ON CONTROL OF MEDITERRANEAN FRUIT FLY (DIPTERA: TEPHRITIDAE) ${ }^{1}$
}

\author{
CRISTHIANE ROHDE ${ }^{2 *}$, NATÁLIA RAMOS MERTZ ${ }^{3}$, ALCIDES MOINO JUNIOR ${ }^{3}$
}

\begin{abstract}
Mediterranean fruit fly (Ceratitis capitata) is one of the world's major pests infesting fruit crops, causing significant losses. However, this insect has a soil phase and is a potential target for entomopathogenic nematodes. The objective of this work was to test the efficiency of the nematodes Steinernema carpocapsae ALL and Heterorhabditis amazonensis JPM4 in controlling larvae and pupae of Ceratitis capitata. Petri dishes with filter paper or pots with $200 \mathrm{~g}$ of soil were used to assess different nematode concentrations; 20 individuals (larvae or pupae) were placed in each container and the nematode suspension was applied at concentrations of $0,140,180,220,260$, and $300 \mathrm{IJs}$ (infective juveniles) $\mathrm{cm}^{-2}$. The nematode horizontal movement was tested using pots with soil and a metal screen at every $10 \mathrm{~cm}$ to define different distances $(0,10,20$, and $30 \mathrm{~cm}$ from the application site). Ten larvae and ten pupae were transferred to every distance; $10 \mathrm{~mL}$ of the nematode suspension $\left(220 \mathrm{IJ} \mathrm{cm}^{-2}\right)$ were applied at the distance zero; $10 \mathrm{~mL}$ of the nematode suspension with $220 \mathrm{IJs} \mathrm{cm}^{-2}$ was applied to each pot, using ten larvae and ten pupae for each evaluation time $(0,10,20$, and 30 days after application of nematodes) to study the effectiveness of these nematodes over time. Both nematodes killed $C$. capitata larvae and pupae, but $S$. carpocapsae ALL was the most effective. However, this nematode showed no ability for horizontal movement, which was found in $H$. amazonensis JPM4 nematodes. Both nematodes showed decreasing efficiency over time.
\end{abstract}

Keywords: Ceratitis capitata. Steinernema carpocapsae. Heterorhabditis amazonensis. Biological control.

\section{NEMATÓIDES ENTOMOPATOGÊNICOS PARA O CONTROLE DA MOSCA-DO- MEDITERRÂNEO (DIPTERA: TEPHRITIDAE)}

\begin{abstract}
RESUMO - A mosca-das-frutas (Ceratitis capitata) é considerada uma das principais pragas da fruticultura, acarretando perdas significativas para este setor. Este inseto passa uma fase de sua vida no solo, sendo alvo em potencial para nematoides entomopatogênicos. O objetivo desse trabalho foi avaliar a eficiência de Steinernema carpocapsae ALL e Heterorhabditis amazonensis JPM4 para o controle de Ceratits capitata (Diptera: Tephritidae). Para a avaliação de diferentes concentrações foram utilizadas placas com papel filtro ou vasos com $200 \mathrm{~g}$ de solo. Para cada recipiente foram transferidos 20 indivíduos (larvas ou pupas) e aplicada a suspensão dos nematoide nas concentrações 140, 180, 220, 260 e $300 \mathrm{JIs} / \mathrm{cm}^{2}$. Para avaliação do deslocamento horizontal, foram utilizados vasos contendo solo e a cada $10 \mathrm{~cm}$ de distância foi colocada uma tela de metal, para delimitar as diferentes áreas $(0,10,20$ e $30 \mathrm{~cm}$ do local de aplicação do nematoide). Para cada área foram transferidas 10 larvas e 10 pupas. Na distância zero foram aplicados de $10 \mathrm{~mL}$ de suspensão dos nematoides contendo 220JIs $/ \mathrm{cm}^{2}$. Para o estudo da eficiência desses nematoides ao longo do tempo, em cada vaso foram aplicados $10 \mathrm{~mL}$ de suspensão de nematoide com $220 \mathrm{JIs} / \mathrm{cm}^{2}$, e em cada período $(0,10,20$ e 30 dias pósaplicação do nematoide) foram transferidas 10 larvas e 10 pupas. Verificou-se que os dois nematoides causaram mortalidade de $C$. capitata, sendo que $S$. carpocapsae ALL foi mais eficiente. Porém, esse nematoide não apresentou capacidade de deslocamento horizontal, característica essa observada para H. amazonensis JPM4. Ambos os nematoides tiveram sua eficiência reduzida ao longo do tempo.
\end{abstract}

Palavras-chave: Ceratitis capitata. Steinernema carpocapsae. Heterorhabditis amazonensis. Controle biológico.

\footnotetext{
*Corresponding author

${ }^{1}$ Received for publication in $03 / 25 / 2020$; accepted in $07 / 30 / 2020$.

${ }^{1}$ Paper extracted from the doctoral thesis of the first author.

${ }^{2}$ Department of Biological and Environmental Sciences, Universidade Tecnológica Federal do Paraná, Medianeira, PR, Brazil; cristhianerohde@utfpr.edu.br - ORCID 0000-0002-5409-0625.

${ }^{3}$ Departament of Entomology, Universidade Federal de Lavras, Lavras, Minas Gerais, Brazil; nataliaertz@gmail.com - ORCID: 0000-0002 -2259-0166, alcmoino@gmail.com-0000-0002-8566-0694.
} 


\section{INTRODUCTION}

Mediterranean fruit fly (Ceratitis capitata) is one of the world's major pests infesting fruit crops, causing significant losses due to direct and indirect damages. Females cause direct damage because of the oviposition during fruit ripening; the larvae forage on the fruit pulp, causing rot and premature fall of fruits. Indirect damages also occur, since this insect is a quarantine pest. The presence of this pest species limits the access of fruits to international markets due to quarantine restrictions imposed by importing countries (MURIITHI et al., 2016).

Ceratitis capitata (Wiedemann) (Diptera: Tephritidae) is one of the most important fruit fly species because it is the most cosmopolitan and invasive species, occurring in all biogeographic regions of the world and, consequently, causing the most damages to fruit production (EGARTNER et al., 2019). The control of fruit flies usually requires more than one method. It can be achieved through cultural, behavioral, legislative, biological, and chemical methods, the latter being the most used (DIAS et al. 2018). However, chemical control using toxic sprays or baits contributes to an imbalance in the ecosystem, affecting natural enemies and nontarget organisms. In addition, pesticides are expensive and can leave toxic residues on fruits, which are prejudicial to the fresh fruit marketing and consumption (MURIITHI et al., 2016).

Entomopathogenic nematodes belonging to the Heterorhabditidae and Steinernematidae families are efficient biological control agents because they present selectivity and harmlessness to the environment and other living organisms, including humans; thus, they are a great resource for integrated pest managements (LABAUDE; GRIFFIN, 2018). These entomopathogens have potential to control insect pests that live in the soil, such as fruit flies, whose larvae fall to the soil to develop into pupae, allowing the action of nematodes (GRIFFIN et al., 2005).

Laboratory and field studies have been developed to determine the effects of species and strains of entomopathogenic nematodes on different developmental stages of $C$. capitata insects and showed high susceptibility for this insect (MALAN; MANRAKHAN, 2009, ROHDE et al., 2010; ROHDE et al., 2012; ROHDE et al., 2013; MINAS et al., 2016; JAMES; MALAN; ADDISON, 2018; CHERGUI et al., 2019).

However, further studies are needed to determine the best conditions and application strategies to achieve maximum efficiency of these entomopathogens in controlling fruit flies. Thus, the objectives of this study were to evaluate the efficiency of applications with different concentrations of the nematodes Steinernema carpocapsae ALL (Rhabdita: Steinernematidae) and Heterorhabditis amazonensis JPM4 (Rhabditida:
Heterorhabditidae) in controlling larvae and pupae of C. capitata in laboratory and greenhouse assays, and to determine the horizontal movement and efficiency of these nematodes over time.

\section{MATERIAL AND METHODS}

\section{Ceratitis capitata insect rearing}

C. capitata pupae from the Center for Nuclear Energy in Agriculture (CENA; Piracicaba, SP, Brazil) were used at the beginning of the breeding; they were maintained under controlled temperature $\left(25 \pm 2{ }^{\circ} \mathrm{C}\right)$, relative humidity $(70 \pm 10 \%)$, and photoperiod (12 hours), as proposed by Minas et al. (2016).

\section{Obtention of entomopathogenic nematodes}

The bioassays were carried out using the $H$. amazonensis JPM4 isolate, from Minas Gerais, Brazil; and S. carpocapsae ALL isolate, from North Carolina, USA. The nematodes were multiplied in vivo, using a method adapted from Woodring and Kaya (1988), using last instar larvae of Galleria mellonella (Linnaeus) (Lepidoptera: Pyralidae).

Entomopathogenic nematode concentration on larvae and pupae of $C$. capitata in Petri dishes

Bioassays were carried out in a randomized design with seven replications. The plots consisted of Petri dishes with 20 individuals. The larva trial was carried out using standardized individuals at the end of the third instar; and the pupa bioassay tested two ages the effect of the nematodes was tested on young (0- to 2-day-old) and old (6- to 8-day-old) pupae. The individuals were transferred to Petri dishes ( 9 $\mathrm{cm}$ diameter) with two sheets of filter paper, where 1 $\mathrm{mL}$ of the nematode suspension ( $H$. amazonensis JPM4 or $S$. carpocapsae ALL) was added at concentrations of 0 (control treatment), 140, 180, 220, 260, and $300 \mathrm{IJs}$ (infective juveniles) $\mathrm{cm}^{-2} ; 1$ $\mathrm{mL}$ of distilled water was used for the control treatment. These Petri dishes were kept in an incubator $\left(25 \pm 1{ }^{\circ} \mathrm{C}\right.$, relative humidity of $70 \pm 10 \%$, and photoperiod of 12 hours). The insects were evaluated at 5 days after application, and the dead ones were analyzed for typical symptoms of death by Steinernema sp. (dark brown color) or Heterorhabditis sp. (red color). In addition, the dead ones were dissected and the presence of nematodes confirmed their death by nematodes.

Entomopathogenic nematode concentration on larvae and pupae of $C$. capitata in soils under laboratory and greenhouse conditions

Bioassays were carried out in a randomized 
design with seven replications. The plots consisted of 1-liter plastic pots with $200 \mathrm{~g}$ of sterilized soil (Typic Hapludox with initial standardized moisture of $25 \%$ ) and $20 \mathrm{C}$. capitata insects. The laboratory experiment was carried out using 20 third-instar larvae and twenty 6- to 8-day-old pupae. The greenhouse experiment was carried out using a mix of ten third-instar larvae and ten 6- to 8-day-old pupae; $10 \mathrm{~mL}$ of nematode suspension $(H$. amazonensis JPM4 or $S$. carpocapsae ALL) at concentrations of 0 (control treatment), 140, 180, 220, 260, and $300 \mathrm{IJs} \mathrm{cm}^{-2}$ were applied, using 10 $\mathrm{mL}$ of distilled water for the control treatment. The pots were kept in an incubator $\left(25 \pm 1{ }^{\circ} \mathrm{C}\right.$, relative humidity of $70 \pm 10 \%$, and photoperiod of 12 hours) or in a greenhouse $\left(10\right.$ to $\left.33{ }^{\circ} \mathrm{C}\right)$. The soil moisture in the pots was corrected when necessary. The same evaluation procedure of the previous bioassay was used at 5 days after application.

\section{Horizontal movement of entomopathogenic nematodes}

Bioassays were carried out in a randomized design with six replications. The plots consisted of plastic pots $(40 \mathrm{~cm}$ long $\times 13 \mathrm{~cm}$ wide $\times 11 \mathrm{~cm}$ high $)$ with sterilized soil (Typic Hapludox with initial standardized moisture of 25\%). A 60-mesh metal screen was placed every $10 \mathrm{~cm}$ to allow the nematodes and prevent $C$. capitata larvae to pass through; this procedure defined different distances $(10,20,30$, and $40 \mathrm{~cm}$ from the nematode application site). A mix of ten third-instar larvae and ten 6- to 8-day-old pupae was applied to each distance; $10 \mathrm{~mL}$ of the nematode suspension $(H$. amazonensis JPM4 or S. carpocapsae ALL) at 220 $\mathrm{IJS} \mathrm{cm}_{\mathrm{S}} \mathrm{cm}^{-2}$ were applied to the distance zero, using 10 $\mathrm{mL}$ of distilled water for the control treatment. The pots were kept in a greenhouse $\left(10\right.$ to $\left.33^{\circ} \mathrm{C}\right)$ and watered evenly when necessary. The insects were evaluated at 10 days after application, following the same procedure of the previous bioassay.

Efficacy of entomopathogenic nematodes in controlling larvae and pupae of $C$. capitata over time

Bioassays were carried out in a randomized design with four treatments for each nematode, with seven replications. The plots consisted of 1-liter plastic pots with $200 \mathrm{~g}$ of sterilized soil (Typic Hapludox with initial standardized moisture of $25 \%) ; 10 \mathrm{~mL}$ of nematode suspension (H. amazonensis JPM4 or S. carpocapsae ALL) at 220 IJs $\mathrm{cm}^{-2}$ were applied to each pot, using $10 \mathrm{~mL}$ of distilled water for the control treatment. The pots were kept in a greenhouse $\left(7\right.$ to $\left.34{ }^{\circ} \mathrm{C}\right)$ and watered evenly when necessary. A mix of ten third-instar larvae and ten 6- to 8-day-old pupae was transferred to each pot at each evaluation time $(0,10,20$, and 30 days after application of nematodes). The insects were evaluated at 10 days after application, following the same procedure of the previous bioassay. The samples were analyzed and then discarded after each evaluation time.

\section{Statistical analysis}

The data were subjected to the Shapiro-Wilk normality test and did not showed normality; thus, they were subjected to non-parametric analyses by the Kruskal Wallis Test $(p \leq 0.05)$, and the values were compared by the Simes-Hochberg test, using the Action Stat Program.

\section{RESULTS AND DISCUSSION}

Entomopathogenic nematode concentration on larvae and pupae of $C$. capitata in Petri dishes under laboratory conditions

All evaluated concentrations of $S$. carpocapsae ALL nematodes killed $C$. capitata larvae and pupae at different ages; the larval stage was the most susceptible, showing mortality rates of $50 \%$ to $80 \%$. This nematode killed $21 \%$ to $50 \%$ young pupae and $15 \%$ to $43 \%$ old pupae (Figure 1 ).

The $C$. capitata larvae mortality rate increased proportionally to the nematodes concentration up to $220 \mathrm{IJs} \mathrm{cm}^{-2}$, and showed relative decreases when using concentrations higher than 220 IJ $\mathrm{cm}^{-2}$. The three highest concentrations used were the best for young pupae. Old pupae showed higher mortality rate for the concentration of $260 \mathrm{IJ} \mathrm{sm}^{-2}$.

The decreases in mortality rate when using concentrations of $S$. carpocapsae ALL nematode greater than $220 \mathrm{IJs} \mathrm{cm}^{-2}$ for C. capitata larvae or $260 \mathrm{IJs}_{\mathrm{cm}} \mathrm{cm}^{-2}$ for pupae were probably due to intraspecific competition of the nematode. According to Gaugler, Wang and Campbell (1994), when a host is infected by entomopathogenic nematodes, a small number of nematodes is required to overcome the host immune system and colonize it until its death. However, when the number of nematodes is very large, intraspecific competition occurs, affecting their survival, development, and reproduction, which reduces their virulence (SELVAN; CAMPBELL; GAUGLER, 1993). 


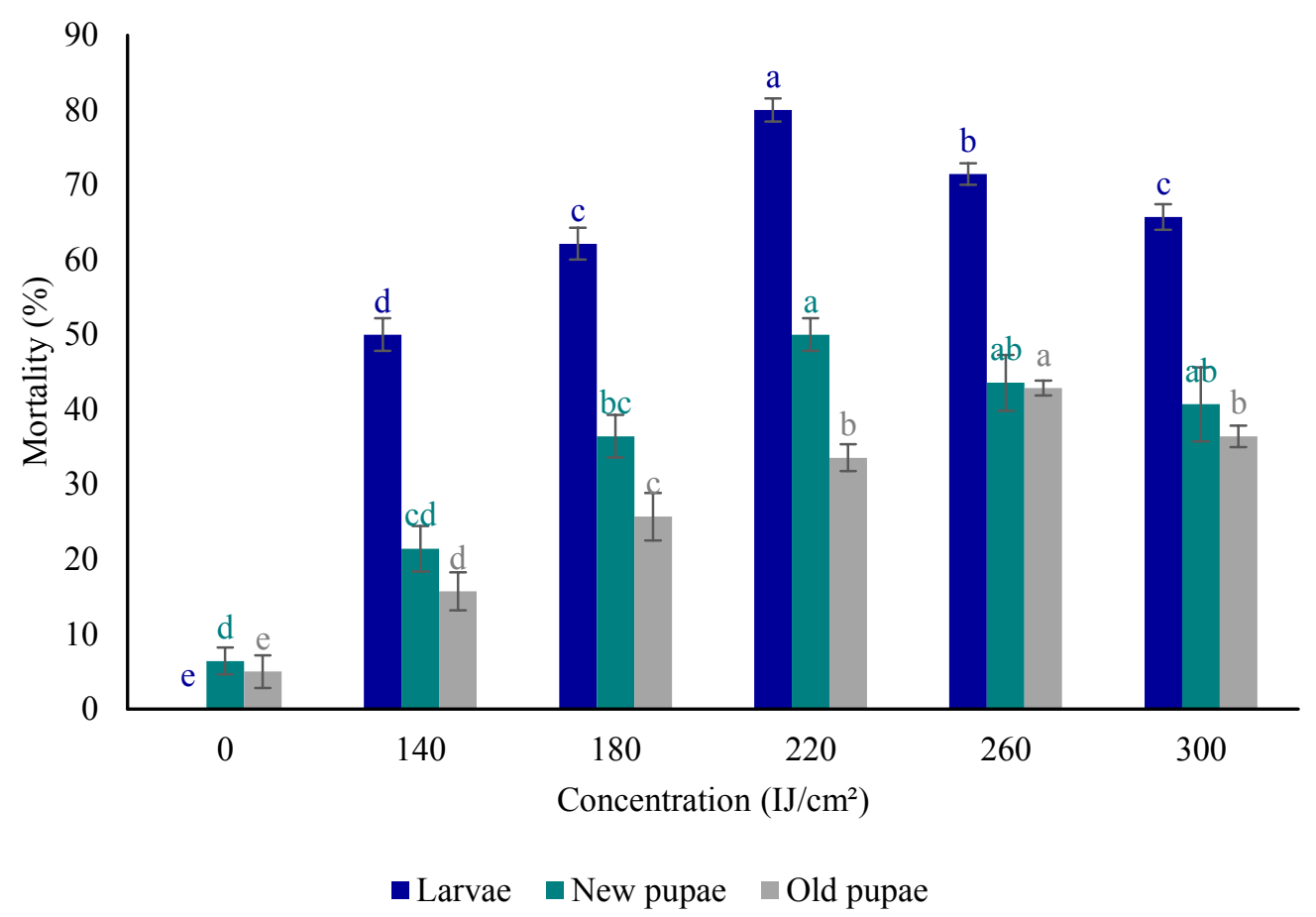

Bars with the same color and letter are not different by the Simes-Hochberg's test $(\mathrm{p} \leq 0.05)$.

Figure 1. Mortality rates (mean \pm standard error) of larvae, young pupae, and old pupae of Ceratitis capitata evaluated at five days after exposure to different concentrations of Steinernema carpocapsae ALL nematodes in Petri dishes under laboratory conditions $\left(25 \pm 1{ }^{\circ} \mathrm{C}\right.$, relative humidity of $70 \pm 10 \%$, and photoperiod of 12 hours).

The all evaluated concentrations of $H$. amazonensis JPM4 nematodes also killed C. capitata larvae and pupae at different ages. The larval stage was also the most susceptible to $H$. amazonensis
JPM4 nematodes, presenting mortality rates of $24 \%$ to $60 \%$, with $28 \%$ to $54 \%$ for young pupae and $11 \%$ to $44 \%$ for old pupae (Figure 2).

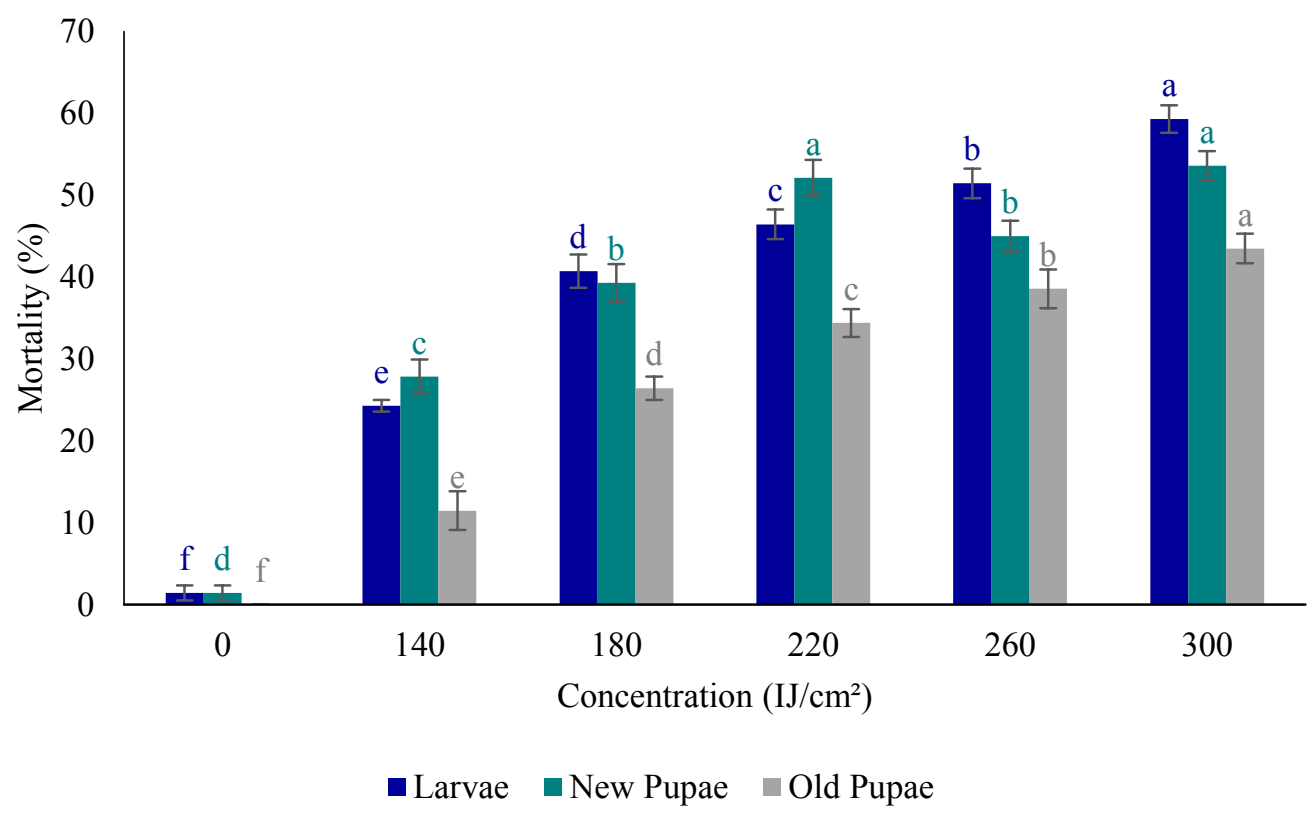

Bars with the same color and letter are not different by the Simes-Hochberg's test $(\mathrm{p} \leq 0.05)$.

Figure 2. Mortality rates (mean \pm standard error) of larvae, young pupae, and old pupae of Ceratitis capitata evaluated at five days after exposure to different concentrations of Heterorhabditis amazonensis JPM4 nematodes in Petri dishes under laboratory conditions $\left(25 \pm 1{ }^{\circ} \mathrm{C}\right.$, relative humidity of $70 \pm 10 \%$, and photoperiod of 12 hours). 
The higher efficiency of $S$. carpocapsae ALL nematodes in controlling $C$. capitata larvae may be due to the relatively small size of infective juveniles (438 to $650 \mu$ ) (ADAMS; NGUYEN, 2002), which facilitates the penetration of Steinernematidae species through natural openings of the host (spiracles, mouth, and anus). Thus, the lower efficiency of $S$. carpocapsae ALL nematodes in controlling $C$. capitata pupae was because of the behavior of the nematode, which is an ambusher species (SHAPIRO ILAN; HAZIR; GLAZER, 2017). Lewis et al. (2006) point out that ambusher nematodes, which wait for the best moment to attack the host, are more effective in finding high-mobility hosts, whereas cruiser nematodes, which move in search for hosts, are more likely to find sedentary hosts.

Infective juveniles of $H$. amazonensis nematodes have body sizes of 567 to $618 \mu$ (ANDALÓ; MOREIRA; MOINO Jr, 2009), larger than $S$. carpocapsae ones. This explains the lower success of using them for the control of $C$. capitata larvae. Studies have shown that $H$. amazonensis are cruiser nematodes (ANDALÓ; MOREIRA; MOINO $\mathrm{Jr}, 2014$ ), which increases their success in searching for low-mobility preys and may have contributed to a higher success in controlling young and old pupae when compared to $S$. carpocapsae nematodes.

Efficiency of $S$. carpocapsae ALL nematodes in controlling $C$. capitata larvae under laboratory conditions has been found in other studies. Rohde et al. (2012) found mortality rates of $C$. capitata larvae higher than $90 \%$. Similar results were found by Foelkel, Monteiro and Voss (2016) for Anastrepha fraterculus (Wiedemann) (Diptera: Tephritidae); by Heve et al. (2017) for Anastrepha suspensa (Loew) (Diptera: Tephritidae); and by Sirjani, Lewis and Kaya (2009) for Bactrocera oleae (Gmelin) (Diptera: Tephritidae). Rohde et al. (2012) tested the efficiency of $S$. carpocapsae ALL nematodes in controlling $C$. capitata pupae and found mortality rate of $20 \%$ when using 200 IJs per insect, equivalent to $100 \mathrm{IJs} \mathrm{cm}^{-2}$.

Efficiency of $H$. amazonensis JPM4 nematodes in controlling $C$. capitata insects was also found by Rohde (2012), who reported mortality rates of $40 \%$ and $41.3 \%$ for larvae and pupae, respectively, when using 200 IJ per insect (equivalent to $100 \mathrm{IJs} \mathrm{cm}^{-2}$ ). Foelkel, Monteiro and Voss (2016) tested H. amazonensis JPM4 nematodes for the control of $A$. fraterculus larvae and found mortality rates of approximately $50 \%$ when applying the nematodes in the soil, in laboratory tests.
Both nematodes present greater virulence to C. capitata larvae than to young and old pupae. This may be due to the greater susceptibility of larvae to entomopathogenic nematodes because of their great locomotion at this stage and great release of $\mathrm{CO}_{2}$, which attracts nematodes (SHAPIRO-ILAN; HAZIR; GLAZER, 2017). The large natural openings in the body of Steinernema and Heterorhabditis larvae and less sclerotized tegument (compared to pupal stage) of Heterorhabditis facilitate the infection of the insect by the nematode. The lower susceptibility of pupae can be related to the small openings of their spiracles, which hinders the penetration of the nematode, or it is due to the protection of the pupa by a sclerotized puparium that hinders the penetration (MINAS et al., 2016).

Similar studies with $C$. capitata insects also reported higher susceptibility of larvae than pupae (ROHDE et al., 2012; MINAS et al., 2016); studies with insects of the species $C$. capitata, Ceratitis rosa Karsch (Diptera: Tephritidae) (MALAN; MANRAKHAN, 2009), Rhagoletis cerasi Linnaeus (Diptera: Tephritidae) (KEPENEKCI; HAZIR; ÖZDEM, 2015), A. suspensa (HEVE et al., 2017), Bactrocera oleae Rossi (Diptera: Tephritidae) (TORRINI et al., 2020), and Bactrocera dorsalis Handel (Diptera: Tephritidae) (GODJO et al., 2018) exposed to different Steinernema and Heterorhabditis nematode species and isolates found no or low susceptibility of pupae to the nematodes.

Young pupae were more susceptible than old pupae to both nematodes, as also found by Chergui et al. (2019), who evaluated the effect of entomopathogenic nematodes on $C$. capitata insects. The tegument of young pupae is under sclerotization process and, thus, more susceptible to nematodes (GODJO et al., 2018).

Entomopathogenic nematode concentration on larvae and pupae of $C$. capitata in soils under laboratory and greenhouse conditions

The mortality rates of larvae and pupae of $C$. capitata in the soil under laboratory conditions increased proportionally to the nematode concentration for both evaluated nematode species. The mortality rates of $C$. capitata insects caused by $S$. carpocapsae ALL nematodes were $43 \%$ to $81 \%$ for larvae, and $25 \%$ to $35 \%$ for pupae (Figure 3 ). The mortality rates of $C$. capitata insects caused by $H$. amazonensis JPM4 nematodes were $21 \%$ to $57 \%$ for larvae and $13 \%$ to $34 \%$ for pupae (Figure 4 ). 


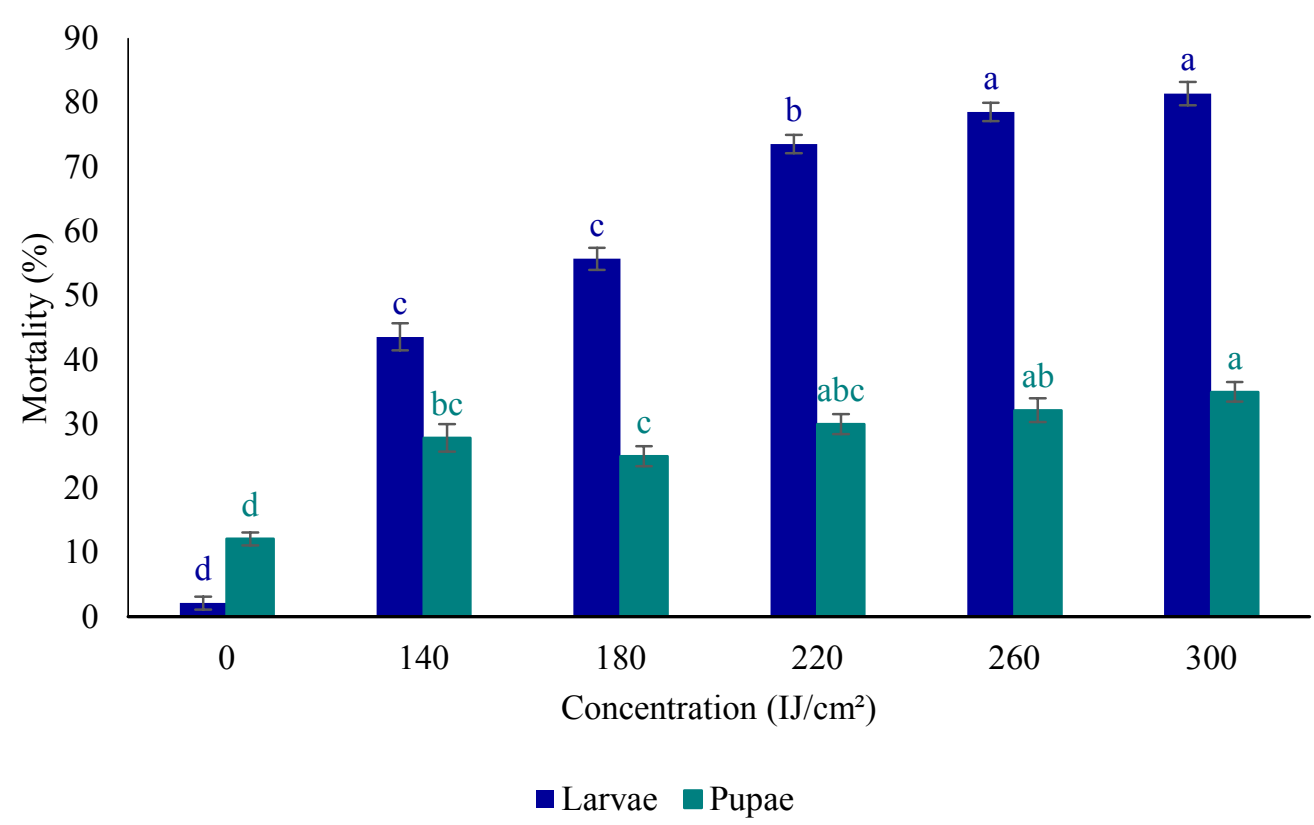

Bars with the same color and letter are not different by the Simes-Hochberg's test $(\mathrm{p} \leq 0.05)$.

Figure 3. Mortality rates (mean \pm standard error) of larvae, young pupae, and old pupae of Ceratitis capitata evaluated at five days after exposure to different concentrations of Steinernema carpocapsae ALL nematodes in soil under laboratory conditions $\left(25 \pm 1^{\circ} \mathrm{C}\right.$, relative humidity of $70 \pm 10 \%$, and photoperiod of 12 hours).

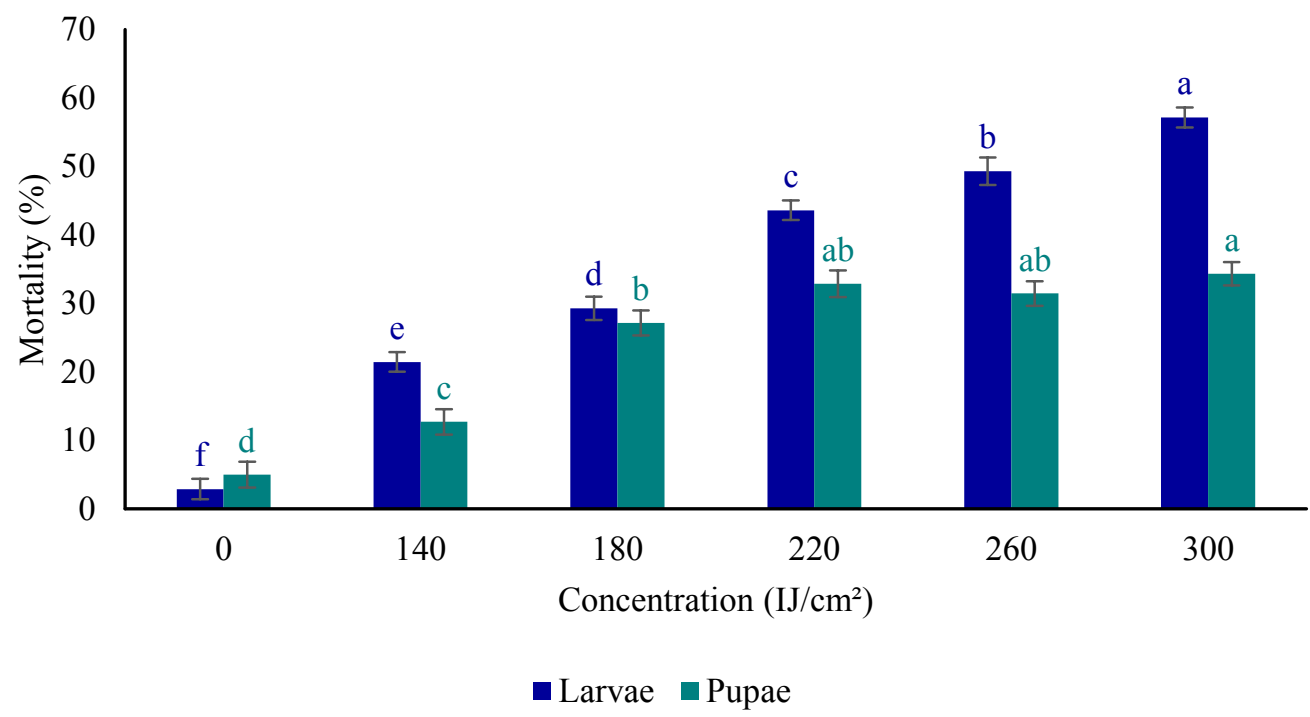

Bars with the same color and letter are not different by the Simes-Hochberg's test $(\mathrm{p} \leq 0.05)$.

Figure 4. Mortality rates (mean \pm standard error) of larvae, young pupae, and old pupae of Ceratitis capitata evaluated at five days after exposure to different concentrations of Heterorhabditis amazonensis JPM4 nematodes in soil under laboratory conditions $\left(25 \pm 1{ }^{\circ} \mathrm{C}\right.$, relative humidity of $70 \pm 10 \%$, and photoperiod of 12 hours).

The infectivity of both nematodes to larvae was similar when they were inoculated in Petri dishes or in the soil under laboratory conditions. However, when considering pupae in the soil, the mortality rate was $16 \%$ lower when exposed to $S$. carpocapsae nematodes and $14 \%$ lower when exposed to $H$. amazonensis nematodes.

Minas et al. (2016) also found that the mortality rate of larvae and pupae of $C$. capitata increases proportionally to the nematode concentration used (Heterorhabditis sp. LPP17, Heterorhabditis sp. LPP14 and Heterorhabditis baujardi LPP7), and found higher susceptibility of larvae, with mortality rates of $80 \%$ to $100 \%$ when exposed to concentrations of 237 and $553 \mathrm{IJ} \mathrm{cm}^{-2}$; they found high mortality rate of pupae 
(approximately 80\%), but using concentrations higher than $800 \mathrm{IJ} \mathrm{cm}^{-2}$ (2.6-fold higher than the concentration used in the present study).

In greenhouse conditions, the results found for both nematodes were similar; the mortality rates of $C$. capitata insects increased proportionally to the nematode concentration (Figure 5). S. carpocapsae ALL nematodes presented greater virulence than $H$. amazonensis JPM4, confirming the results found under laboratory conditions.

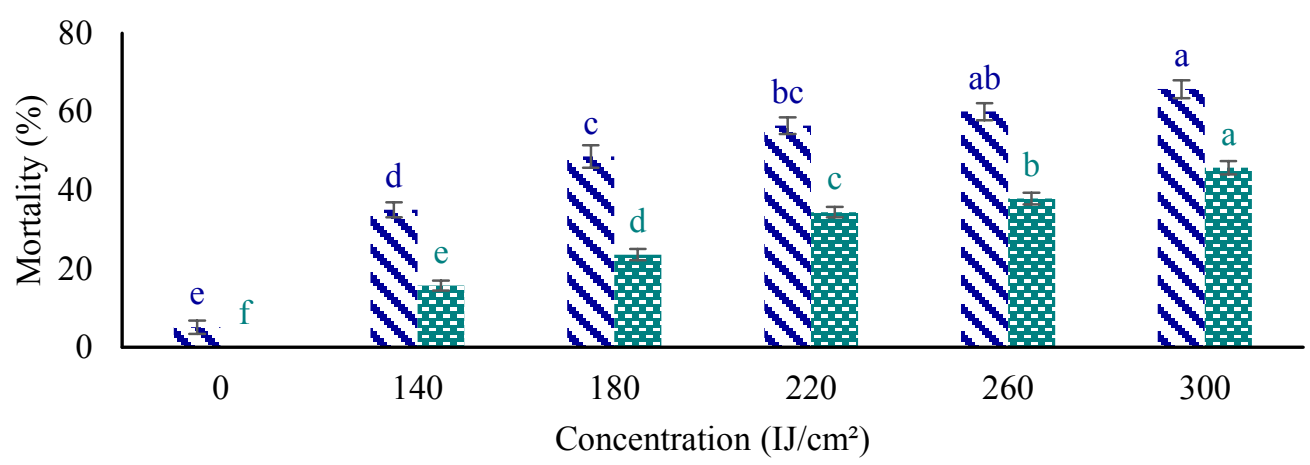

-Steinernema carpocapsae 모 Heterorhabditis amazonensis

Bars with the same color and letter are not different by the Simes-Hochberg's test $(p \leq 0.05)$.

Figure 5. Mortality rates (mean \pm standard error) of larvae, young pupae, and old pupae of Ceratitis capitata evaluated at five days after exposure to different concentrations of Steinernema carpocapsae ALL and Heterorhabditis amazonensis JPM4 nematodes in soil under laboratory conditions $\left(25 \pm 1{ }^{\circ} \mathrm{C}\right.$, relative humidity of $70 \pm 10 \%$, and photoperiod of 12 hours).

The efficiency of these nematodes in greenhouse conditions was approximately $20 \%$ lower than that found for larvae in soil under laboratory conditions. This difference was because the $C$. capitata larvae and pupae were evaluated separately in laboratory bioassays, but in greenhouse conditions, the effect of the entomopathogens was assessed together for the two stages. Therefore, the pupal stage is less susceptible, showing lower mortality than the larval stage evaluated in the bioassay.

Another factor that may have contributed to this lower mortality is the air temperature, which affects soil temperature. Temperature variations were observed inside the greenhouse throughout the experiment period, with minimum of $10{ }^{\circ} \mathrm{C}$ and maximum of $33{ }^{\circ} \mathrm{C}$.

In general, $S$. carpocapsae nematodes show higher virulence when kept at temperatures between 20 and $30{ }^{\circ} \mathrm{C}$ (ROHDE et al., 2010; MASTORE et al., 2019). El-Sadawy (2001) found higher virulence of species of the genus Heterorhabditis when they were kept at $25^{\circ} \mathrm{C}$.

The nematodes $S$. carpocapsae ALL and $H$. amazonensis JPM4 did not reach 100\% mortality rate of $C$. capitata insects in any of the evaluated concentrations, showing the need for assessing the effect of higher concentrations. However, the use of higher concentrations is economically unviable, mainly for large agricultural areas, because of the product availability; thus, the use of low rates of the product combined with other control methods in integrated pest management is more viable. The concentration of $220 \mathrm{IJ} \mathrm{sm} \mathrm{cm}^{-2}$ used in the present work caused considerable reduction in pest population and was used in the following bioassays.

\section{Horizontal movement of entomopathogenic nematodes}

The $S$. carpocapsae nematodes killed $C$. capitata insects only in the site where they were applied $(0$ to $10 \mathrm{~cm}) . H$. amazonensis nematodes killed $C$. capitata insects in the site where they were applied $(0$ to $10 \mathrm{~cm})$ and at the distance of $20 \mathrm{~cm}$ away (Figure 6).

The low mortality rate of $C$. capitata insects caused by $S$. carpocapsae nematodes in the other distances showed that this nematode had no ability to move horizontally to reach the insects at those distances. These nematodes are ambushers, they wait the hosts to approach to attack them; they have less mobility and great effectiveness against highmobility hosts (LEWIS et al., 2006). Morton and García-del-Pino (2009) tested the vertical movement ability of this nematode and found higher concentration of IJs in the soil surface than in deeper layers, confirming the low migration capacity of this entomopathogen. 


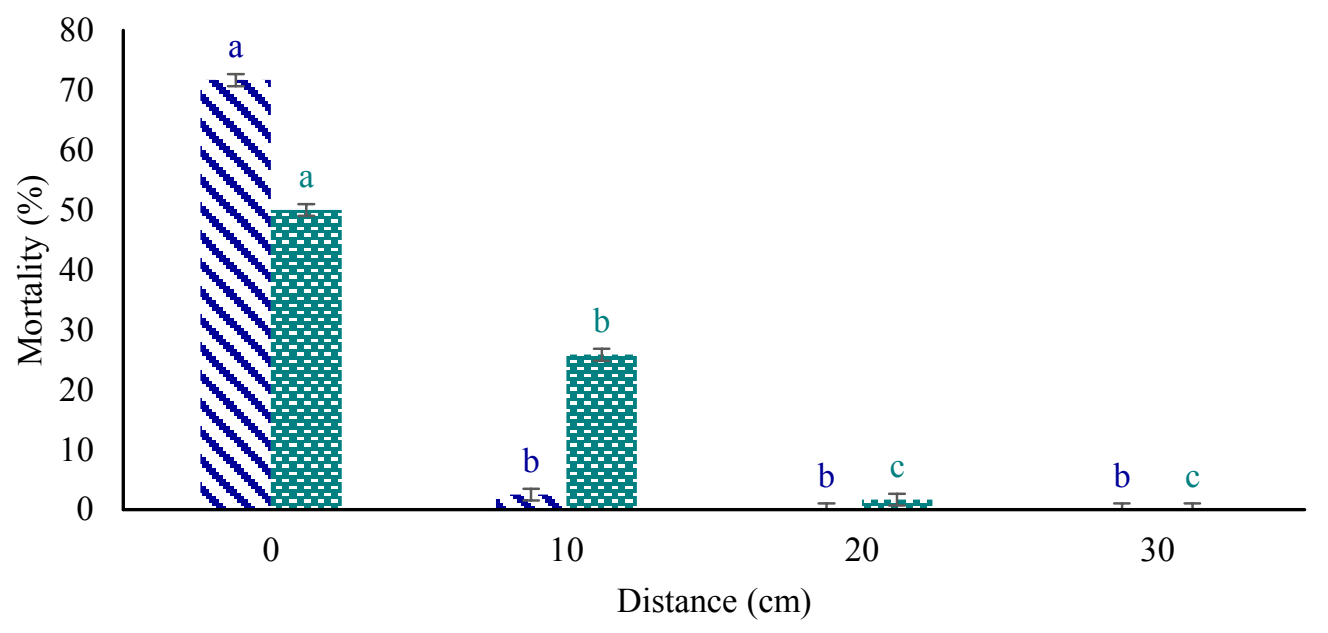

Steinernema carpocapsae $\quad$ Heterorhabditis amazonensis

Bars with the same color and letter are not different by the Simes-Hochberg's test ( $\mathrm{p} \leq 0.05)$.

Figure 6. Mortality rates (mean \pm standard error) of Ceratitis capitata insects evaluated at 10 days after exposure to Steinernema carpocapsae ALL and Heterorhabditis amazonensis JPM4 nematodes, at different distances from the nematode application site in greenhouse conditions.

Contrastingly, H. amazonensis are cruiser nematodes (ANDALÓ; MOREIRA; MOINO Jr, 2014), which is confirmed by the results found for the migration ability of this nematode. Andaló et al. (2012) found that this nematode can kill larvae of $G$. mellonella and Spodoptera frugiperda (Smith) (Lepidoptera: Noctuidae) at up to $60 \mathrm{~cm}$ away, in sand columns.

Efficacy of entomopathogenic nematodes in controlling larvae and pupae of $C$. capitata over time

Both nematodes ( $S$. carpocapsae and $H$. amazonensis) presented a decreasing virulence over time. S. carpocapsae nematodes killed $C$. capitata insects in all evaluation times, but the mortality rates decreased $21 \%, 41 \%$, and $89 \%$ at 10,20 , and 30 days after the nematode application, respectively, when compared to the mortality rate of insects in contact with nematodes on the same day they were applied (day 0 ). The $H$. amazonensis nematodes presented decreases in mortality rates of approximately $58 \%$ and $94 \%$ at 10 and 20 days after the nematode application, respectively, when compared to those at day 0 , and presented mortality rate of zero for insects at 30 days after the nematode application (Figure 7).

$S$. carpocapsae nematodes remained virulent to $C$. capitata insects even at 20 days after the nematode application, a longer time than that found for $H$. amazonensis nematodes, which maintained the same virulence from day 0 only until 10 days after application. These results denote that the control of $C$. capitata insects in soil using $S$. carpocapsae nematodes requires fewer applications than that using $H$. amazonenis nematodes. However, further studies with these nematodes under field conditions and with presence of host insects are needed to evaluate the nematode maximum persistence and virulence, and determine the adequate interval between applications to control fruit flies.

Several factors can affect the persistence, mobility, development, and reproduction of entomopathogenic nematodes over time, thus affecting their infectivity. Temperature, humidity, and ultraviolet radiation are the most important of these factors, because their extremes can reduce the nematode survival, mainly of infective juveniles, and affect other parameters.

The optimum temperature, humidity, and ultraviolet radiation ranges for the activity of entomopathogenic nematodes vary according to the species and isolates. These entomopathogens, in general, remain viable in areas with temperatures between 15 and $35{ }^{\circ} \mathrm{C}$ (ULU; SUSURLUK, 2014; KHOURY et al., 2018), soil moistures that allow for the formation of a free water film between soil particles to prevent desiccation and allow the nematodes to move and survive (SHAPIRO-ILAN; HAN; DOLINSKI, 2012), and low exposure to ultraviolet radiation (SHAPIRO-ILAN; HAN; DOLINSKI, 2012). 


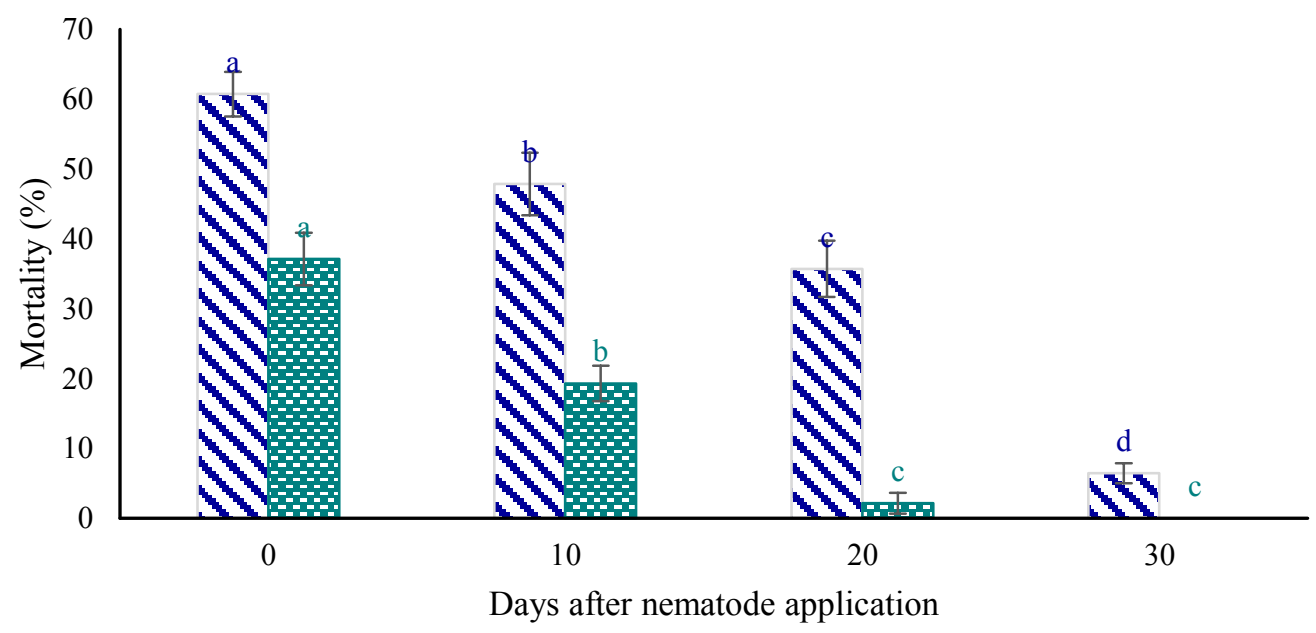

- Steinernema carpocapsae Heterorhabditis amazonensis

Bars with the same color and letter are not different by the Simes-Hochberg's test $(\mathrm{p} \leq 0.05)$.

Figure 7. Virulence of Steinernema carpocapsae ALL and Heterorhabditis amazonensis JPM4 nematodes to Ceratitis capitata insects evaluated at different days after the nematode application in the soil, under greenhouse conditions.

Soil moisture was probably not a factor responsible for the decreases in nematode virulence, since the soil had its initial moisture content standardized to $25 \%$, which was maintained throughout the bioassay through irrigation. This initial soil moisture of $25 \%$ was used because it was the moisture in which $S$. carpocapsae ALL nematodes had higher efficiency in controlling $C$. capitata larvae in bioassays carried out by Rohde et al. (2010).

Temperature may have affected the nematode virulence because of its high variation in the greenhouse throughout the bioassay, with minimum of $7{ }^{\circ} \mathrm{C}$ and maximum of $34{ }^{\circ} \mathrm{C}$. Rohde et al. (2010) found that infectivity is proportional to increases in temperature, with maximum mortality rates of $86.7 \%$ and $80.0 \%$ caused by $S$. carpocapsae and Heterorhabditis species, respectively, at $31{ }^{\circ} \mathrm{C}$. The high exposure to ultraviolet radiation may have also affected the performance of the entomopathogen. Shapiro-Ilan, Hazir and Leite (2015) found that $S$. carpocapsae nematodes are less susceptible to desiccation and ultraviolet radiation than Heterorhabditis species, which may explain the greater decrease in gradual virulence of $S$. carpocapsae ALL when compared to that of $H$. amazonensis JPM4 nematodes.

\section{CONCLUSION}

The nematodes Steinernema carpocapsae ALL and Heterorhabditis amazonensis JPM4 killed larvae and pupae of Ceratitis capitata, and the first stage of development of the insect was the most susceptible. S. carpocasae ALL was the most virulent nematode species, reducing the $C$. capitata population by $66 \%$ when applied to the soil, under greenhouse conditions, and at a concentration of 300 IJs $\mathrm{cm}^{-2}$. Under these same conditions, the nematodes $H$. amazonensis JPM4 killed nearly $46 \%$ of the $C$. capitata population. The nematodes $S$. carpocapsae ALL were not capable of horizontal migration, a characteristic found for the nematodes $H$. amazonensis JPM4 which migrated to distances of up to $20 \mathrm{~cm}$. The efficiency of the nematodes $S$. carpocapsae ALL and H. amazonensis JPM4 in controlling $C$. capitata insects decreased over time, and $H$. amazonensis JPM4 presented the highest decreases.

\section{REFERENCES}

ADAMS, B. J.; NGUYEN, K. B. Taxonomy and systematics. In: GAUGLER, R. (Ed). Entomopathogenic nematology. Wallingford, Oxon: CABI Publishing, 2002. cap. 1, p. 1-28.

ANDALÓ, V. et al. Movement of Heterorhabditis amazonesis and Steinernema arenarium in search of corn fall armyworm larvae in artificial conditions. Scientia Agricola, 3: 226-230, 2012.

ANDALÓ, V.; MOREIRA, G. F.; MOINO Jr, A. Studies of two new populations of Heterorhabditis amazonensis (Rhabditida: Heterorhabditidae). Nematropica, 39: 199-211, 2009.

ANDALÓ, V.; MOREIRA, G. F.; MOINO Jr, A. Heterorhabditis amazonensis RSC5 (Rhabditida: Heterorhabditidae) movement and host recognition. 
Revista Colombiana de Entomologia, 40: 91-97, 2014.

CHERGUI, S. et al. Efficacy of Turkish isolate of Steinernema feltiae (Rhabditida: Steinernematidae) in controlling the Mediterranean fruit fly, Ceratitis capitata (Wiedemann) (Diptera: Tephritidae), under laboratory conditions. Egyptian Journal of Biological Pest Control, 29: 01-07, 2019.

DIAS, N. P. et al. Fruit fly management research: A systematic review of monitoring and control tactics in the world. Crop Protection, 12:187:200, 2018.

EGARTNER, A. et al. Recent records of the Mediterranean fruit fly, Ceratitis capitata (Tephritidae, Diptera), in Austria. IOBC-WPRS Bulletin, 146: 143-152, 2019.

EL-SADAWY, H. A. Effect of temperature and soil moisture on the infectivity of some entomopathogenic nematodes against larvae of the rice moth and flesh fly. International Journal of Nematology, 11: 58-62, 2001.

FOELKEL, E.; MONTEIRO, L. B.; VOSS, M. Virulence of nematodes against larvae of the southAmerican fruit fly in laboratory using soil from Porto Amazonas, Paraná, Brazil, as substrate. Ciência Rural, 46: 405-410, 2016.

GAUGLER, R.; WANG, Y.; CAMPBELL, J. F. Aggressive and evasive behaviors in Popillia japonica (Coleoptera: Scarabaeidae) larvae: defences against entomopathogenic nematode attack. Journal of Invertebrate Pathology, 64: 193-199, 1994.

GODJO, A. et al. Pathogenicity of indigenous entomopathogenic nematodes from Benin against mango fruit fly (Bactrocera dorsalis) under laboratory conditions. Biological Control, 117: 68$77,2018$.

GRIFFIN, C. et al. Biology and behaviour. In: GREVAL, P., EHLERS, R. U., SHAPIRO-ILAN, D. (Eds.). Nematodes as Biocontrol Agents. Wallingford, Oxon: CABI Publishing, 2005. cap 2, p. 47-64.

HEVE, W. K. et al. Biological control potential of entomopathogenic nematodes for management of caribbean fruit fly, Anastrepha suspensa Loew (Tephritidae). Pest Management Science, 73: 1220 1228, 2017.

KEPENEKCI, I.; HAZIR, S.; ÖZDEM, A. Evaluation of native entomopathogenic nematodes for the control of the erupean cherry fruit fly Rhagoletis cerasi L. (Diptera: Tephritidae) larvae in soil. Turkish Journal of Agriculture and Forestry, 39: 74-79, 2015

KHOURY, Y. E. et al. Effect of temperature on the pathogenicity of mediterranean native entomopathogenic nematodes (Steinernematidae and Heterorhabditidae) from natural ecosystems. Redia, 101: 123-127, 2018

LEWIS, E. E. et al. Behavioral ecology of entomopathogenic nematodes. Biological Control, 38: 66-79, 2006

MALAN, A. P.; MANRAKHAN, A. Susceptibility of the mediterranean fruit fly (Ceratitis capitata) and the natal fruit fly (Ceratitis rosa) to entomopathogenic nematodes. Journal of Invertebrate Pathology, 100: 47-49, 2009

JAMES, M.; MALAN, A. P.; ADDISON, P. Surveying and screening south african entomopathogenic nematodes for the control of the mediterranean fruit fly, Ceratitis capitata (Wiedemann). Crop Protection, 105: 41-48, 2018.

LABAUDE, S.; GRIFFIN, C. Transmission success of entomopathogenic nematodes used in pest control. Insects, 72: 1-20, 2018.

MASTORE, M. et al. Susceptibility to entomopathogens and modulation of basal immunity in two insect models at different temperatures. Journal of Thermal Biology, 79: 15-23, 2019.

MINAS, R. S. et al. Potential of entomopathogenic nematodes (Rhabditida: Heterorhabditidae) to control Mediterranean fruit fly (Diptera: Tephritidae) soil stages. Nematoda, 3: 1-14, 2016.

MORTON, A.; GARCÍA-DEL-PINO, F. Ecological characterization of entomopathogenic nematodes isolated in stone fruit orchard soils of mediterranean areas. Journal of Invertebrate Pathology, 102: 203 $-213,2009$.

MURIITHI, B. W. et al. Impact assessment of Integrated Pest Management (IPM) strategy forsuppression of mango-infesting fruitflies in Kenya. Crop Protection, 81: 20-29, 2016.

ROHDE, C. et al. Influence of soil temperature and moisture on the infectivity of entomopathogenic nematodes (Rhabditida: Heterorhabiditidae e Steinernematidae) against larvae of Ceratitis capitata (Wiedemann) (Diptera: Tephritidae). Neotropical Entomology, 39: 608-611, 2010

ROHDE, C. et al. Selection of entomopathogenic nematodes for the controlo of the fruit fly Ceratitis 
capitata (Diptera: Tephritidae). Revista Brasileira de Ciências Agrárias, 7: 797-802, 2012.

ROHDE, C. et al. Compatibilidade de nematóides entomopatogênicos e extratos vegetais aquosos visando o controle da mosca-das-frutas Ceratitis capitata (Wiedemann) (Diptera: Tephritidae). Semina, 34: 1033-1042, 2013.

SELVAN, S.; CAMPBELL, J. F.; GAUGLER, R. Density-dependent effects on entomopathogenic nematodes (Heterorhabditidae and Steinernematidae) within an insect host. Journal of Invertebrate Pathology, 62: 278-284, 1993.

SHAPIRO-ILAN, D. I; HAN, R.; DOLINKI, C. Produção de nematóides entomopatogênicos e tecnologia de aplicação. The Journal of Nematology, 44: 206 - 217, 2012.

SHAPIRO-ILAN, D. I., HAZIR, S., LEITE, L. Viability and virulence of entomopathogenic nematodes exposed to ultraviolet radiation. Journal of Nematology, 47:184-189, 2015.

SHAPIRO-ILAN, D. I.; HAZIR, S.; GLAZER, I. Basic and applied research: entomopathogenic nematodes. In: LACEY, L. A. (Ed.). Microbial control of insect and mite pests: from theory to practice. London: Academic Press, 2017. cap. 6, p. 91-105.

SIRJANI, F. O.; LEWIS, E. E.; KAYA, H. K. Evaluation of entomopathogenic nematodes against the olive fruit fly Bactrocera oleae (Diptera: Tephritidae). Biological Control, 38: 124-133, 2009.

TORRINI, G., et al. Entomopathogenic nematodes as potential biocontrol agents against Bactrocera oleae (Diptera: Tephritidae). Biocontrol Science Technology, 30:1-12, 2020.

ULU, T. C., SUSURLUK, I. A. Heat and desiccation tolerances of Heterorhabditis bacteriophora strains and relationships between their tolerances and some bio-ecological characteristics. Invertebrate Survival Journal, 11: 4-10, 2014.

WOODRING, J. L.; KAYA, H. K. Steinernematidae and Heterorhabditidae nematodes: a handbook of techniques. Nemathode Subcommittee on the Southern Regional Project S135 - Entomopathogens for use in Pest Management Systems, Arkansas: Southern Cooperative, 1988. (Series Bulletin, 331). 